\title{
Bioerosion in ancient and contemporary corals of the genus Porites: patterns and palaeoenvironmental implications
}

\author{
R. Klein, O. Mokady, Y. Loya \\ George S. Wise Faculty of Life Sciences, Department of Zoology, Tel Aviv University, Ramat Aviv 69978, Israel
}

\begin{abstract}
Fossil and modern colonies of Porites corals were collected from recent and ancient reefs in different localities along the Gulf of Eilat, Red Sea. Coral slabs were examined qualitatively and quantitatively for traces of bioeroding organisms. Burrows found in the fossil corals were remarkably preserved, enabling comparison with modern burrows. The most important borers were worms (sipunculids and polychaetes; 35 to $47 \%$ ), while sponges showed relatively low bioerosion activity (10 to $32 \%$ ). Total bioeroded area in the slabs was similar for both recent and fossil Porites (ca $3 \%$ ). However, the number of eroding individuals was significantly higher in fossil corals $(p<0.05)$. It is suggested that a higher number of eroding individuals in fossil corals may indicate elevated levels of primary productivity in the Red Sea during periods of the late Quaternary.
\end{abstract}

\section{INTRODUCTION}

Bioerosion is the destruction of substrate by biological agents, and in coral reef zones is generally caused by boring, etching and grazing organisms (Hutchings \& Peyrot-Clausade 1988). The structure and form of ancient and modern coral reefs is the consequence of the interaction between reef growth and reef destruction (Hutchings 1986). Bioeroders, including polychaete worms, sponges, bivalve molluscs and others, weaken the substrate by mechanical and chemical mechanisms. Apart from a direct erosion of the substrate, their activity is important in formation of bottom sediments (Warme 1975). Several studies of bioeroding communities stress the variability in rates and composition over time and space (Hutchings 1986).

The coastline along the Gulf of Eilat and the Sinai peninsula (Red Sea) is fringed by a narrow belt of modern coral reefs (Loya \& Slobodkin 1971, Loya 1972). A well-preserved belt of 3 elevated fossil-reef terraces stretches along the coast of southern Sinai (Gvirtzman et al. 1977). These terraces were formed during periods of late Quaternary high-stand sea levels, and were dated as follows: the Upper Terrace as older than $250000 \mathrm{yr}$; the Middle Terrace as ca 140000 to 200000 $\mathrm{yr}_{i}$ the Lower Terrace as 108000 to $140000 \mathrm{yr}$. The modern offshore fringing reef was dated as $10000 \mathrm{yr}$ and younger (Gvirtzman et al. 1973, see also Klein et al. 1990). Corals from both ancient and recent reefs exhibit intra-skeletal traces of boring organisms.

The coexistence of reefs and bioeroding organisms is evidently a relationship which has lasted at least 550 million уг (Risk \& MacGeachy 1978). Bioerosion activity in modern reef corals has been studied by many authors (e.g. Highsmith 1981a, Highsmith et al. 1983, Kiene 1988, Peyrot-Clausade \& Brunel 1990). However, Bromley et al. (1990) mentioned that too little is known about the biology of bioerosion processes to use it as a palaeontological tool. Furthermore, Hutchings (1986) emphasized that whether past and present compositions of bioeroding organisms in reef corals are similar has not been evaluated, and that comprehensive descriptions of boring communities are needed in both ancient and modern reefs, in order to understand the long term significance of boring on reefs'.

The coral genus Porites is abundant in the Sinai fossil terraces and is well preserved (Klein et al. 1990). Since this coral genus is also abundant in contemporary reefs of Eilat and Sinai (Loya 1972), it can be used as a model for a comparative evaluation of present and past bioeroding communities.

In the current study we (1) survey coral slices for bioerosion activity, (2) quantitatively compare the intensity of erosion, as well as community composition 

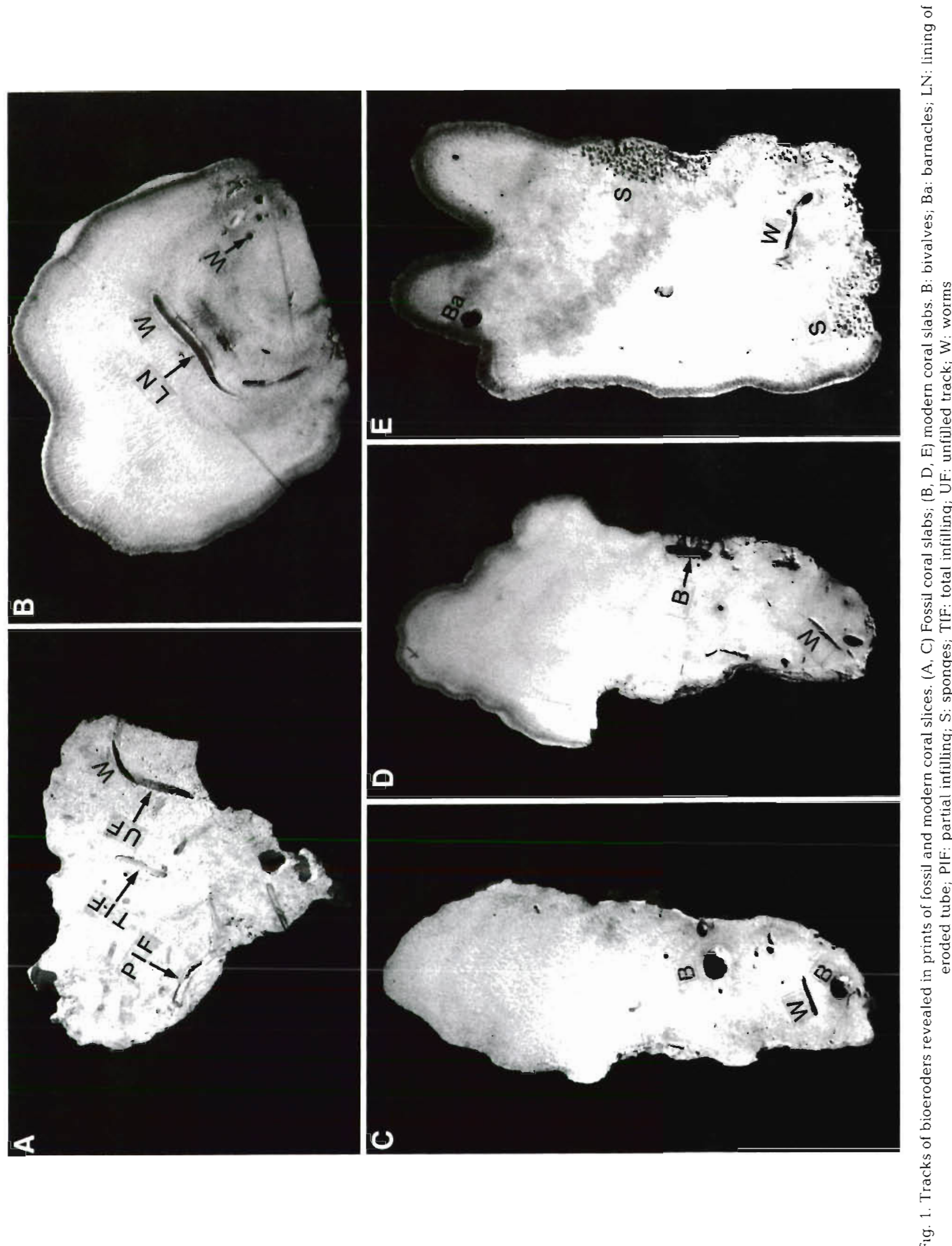
of the eroding agents in living and fossil corals, and (3) use the infaunal traces as possible palaeoenvironmental indicators.

\section{MATERIALS AND METHODS}

Slabs of 77 corals sampled from the Gulf of Eilat, Red Sea, including 31 fossil and 46 recent colonies of the genus Porites, were examined in terms of number of bioeroding individuals, and the amount of eroded area attributed to each taxon. Modern living corals were sampled from the fringing reefs of Eilat and several reef localities in southern Sinai at water depths of 3 to $25 \mathrm{~m}$. Fossil corals were sampled from the elevated late Quaternary fossil reefs near Sharem-el-Sheikh, Sinai peninsula. The sampled corals were categorized according to their collection sites: SF, Sinai fossil ( $\mathrm{n}=$ 31); $S R$, Sinai recent $(n=18)$; $E R$, Eilat recent $(n=28)$. For comparative purposes, Eilat and Sinai recent corals were pooled together and termed PR, pooled recent.

A slice of coral skeleton was cut from each of the heads along the maximal growth axis, using a diamond rock saw. The slices obtained were visually examined for traces of bioeroders. Taxonomic groups were identified according to track characteristics (i.e. shape, texture and size; see 'Results'). To clear uncertainties in identification of eroders, X-ray images of the coral slices were examined (similar to Hein \& Risk 1975). Traces of each taxon were counted for number of individuals. We consistently selected the side of the coral slice containing more individuals. Eroded areas were measured on photocopies of the coral slices (Sammarco \& Risk 1990), using a computer-linked digitizer (Summagraphics MM1812). The results were expressed as (1) percent of the total area eroded by each taxon and (2) relative percent of erosion attributed to each taxon.
Statistical analyses were performed according to Sokal \& Rohlf (1969). The arcsine transformation for percentages was used where necessary

\section{RESULTS}

Traces of bioeroding animals were detected in the coral slabs. Boring organisms encountered in the study were categorized into 4 major groups: worms (sipunculids and polychaetes), sponges, bivalve molluscs and unidentified organisms, termed 'others' (e.g. barnacles, gastropods, foraminiferans). Fig. 1 shows examples of the various borehole traces found in the slabs.

Worms generally create elongated sinuous tubes, with or without $\mathrm{CaCO}_{3}$ lining, typically unrestricted in location within the coral slice. In cases where sections were perpendicular to the tube (rather than parallel), a round borehole resulted. Imprints of eroding sponges appear as small irregular galleries, usually concentrated at the slab's base and periphery. Bivalve excavations were normally large, oval or clavate in shape, occasionally lined, or even containing relicts of the valves. These excavations were not restricted to a particular location within the slabs. All unclassified burrows, tubes and boreholes were related to the group termed 'others'.

The percent of eroded coral surfaces is listed in Table $1 \mathrm{~A}$, according to the corresponding taxonomic group and the various reef sites. The total percent of erosion for all studied reefs was found within a narrow range of 3.04 to $3.74 \%$. Two-way ANOVA revealed significant differences among the various taxa $(\mathrm{p}<$ 0.001 ), but did not show significant differences among the studied reefs (SF, SR, ER; $\mathrm{p}>0.05$ ). The PR group (pooled data for recent corals, SR and ER) was included for demonstrative purposes only (see Figs. 2B \& 3).

Table 1. Summary of bioerosion data. (A) Eroded area expressed as average percent of the coral slice surface area. (B) Relative percent of erosion attributed to different taxa in each of the studied reefs. First line in each entry: average; second line: standard deviation. Relative percentages of erosion (B) were computed using raw data and not directly from the averages presented in $A$. n: number of coral samples; SF: Sinai fossil; SR: Sinai recent; ER: Eilat recent; PR: pooled recent

\begin{tabular}{|c|c|c|c|c|c|c|c|c|c|}
\hline & \multicolumn{5}{|c|}{ (A) $\%$ Erosion of coral surface } & \multicolumn{4}{|c|}{ (B) Relative \% of erosion } \\
\hline & Worms & Sponges & Bivalves & Others & Total & Worms & Sponges & Bivalves & Others \\
\hline SF & 0.97 & 0.45 & 0.65 & 0.98 & 3.04 & 42.01 & 10.82 & 19.40 & 27.77 \\
\hline $\mathrm{n}=31$ & 1.10 & 1.03 & 0.96 & 1.74 & 2.65 & 30.67 & 20.42 & 25.43 & 27.64 \\
\hline & 0.76 & 1.34 & 1.18 & 0.46 & 3.74 & 35.27 & 32.13 & 19.85 & 12.75 \\
\hline $\mathrm{n}=18$ & 0.60 & 1.56 & 1.95 & 0.95 & 3.44 & 30.69 & 25.34 & 22.02 & 19.86 \\
\hline ER & 1.36 & 0.67 & 0.60 & 0.79 & 3.43 & 47.39 & 15.58 & 18.46 & 18.57 \\
\hline $\mathrm{n}=28$ & 1.20 & 1.57 & 0.94 & 1.18 & 2.36 & 31.20 & 22.53 & 27.91 & 21.44 \\
\hline PR & 1.13 & 0.93 & 0.83 & 0.66 & 3.55 & 42.65 & 22.05 & 19.01 & 16.29 \\
\hline $\mathrm{n}=46$ & 1.05 & 1.60 & 1.45 & 1.11 & 2.83 & 31.56 & 25.01 & 25.78 & 21.03 \\
\hline
\end{tabular}


Table 1B summarizes the relative percentage of bioerosion computed for each of the groups. Calculation of the relative percent of erosion for each taxon

\section{A}

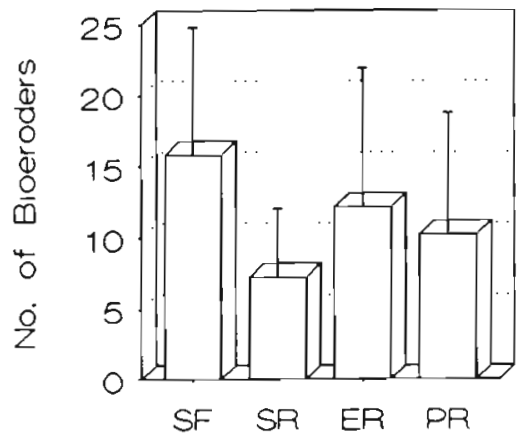

B

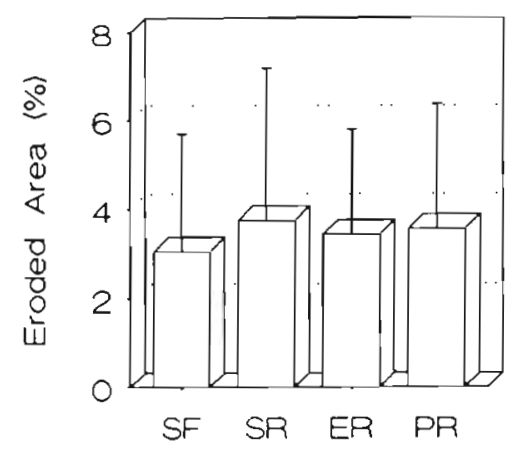

Fig. 2. Bioerosion in corals of modern and fossil coral reefs. (A) Average number of bioeroding individuals (+SD). (B) Total eroded area expressed as average percent of the coral slice surface area (+SD). SF: Sinai fossil; SR: Sinai recent; ER: Eilat recent; PR: pooled recent
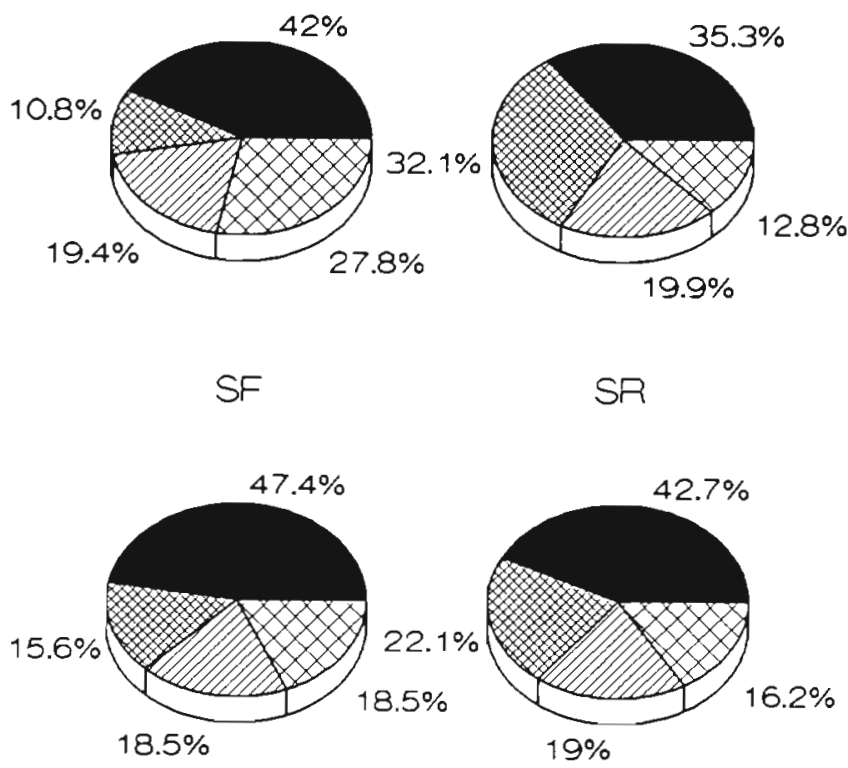

ER PR in Table 1B was based on the raw data, and not on the averages presented in Table $1 \mathrm{~A}$. For example, the value $47.39 \%$, representing the relative part of erosion by worms (ER reefs), is not a result of the ratio $1.36 / 3.43$, but rather an average of the ratios calculated from the raw data. Statistical analysis of these data (2-way ANOVA) indicated the same trend as for the percent eroded area, in terms of differences among reefs and taxonomic groups $(\mathrm{p}>0.05, \mathrm{p}$ $<0.001$, respectively). In all reefs studied, worms showed the highest percentage of bioerosion. In comparing corals from different reefs, worms and bivalves showed very similar erosion activity, while sponges and 'others' varied in their erosion intensity (Fig. 3).

A comparison of the total number of boring individuals between reefs showed that the highest number was found in fossil corals sampled from the Sinai elevated terraces (Fig. 2A). One-way ANOVA followed by a priori tests revealed that this number was significantly higher ( $p<0.05$ ) than the number found in recent corals, both SR and ER, which were similar in their number of boring individuals ( $p>0.05$ ).

\section{DISCUSSION}

Bromley et al. (1990) raised the question of whether different bioerosion sculptures and trace fossils can inform us about the general environment of the eroded substrate. Due to the profound importance of this phenomenon, both in modern and ancient reefs (Hutchings 1986), it was interesting to investigate and

\section{Worms}

\section{Sponges}

Qllf Bivalves

XXX Others
Fig. 3. Relative percent of bioerosion attributed to different taxa in each of the reefs (see abbreviations in Fig. 2) 
compare bioerosional activity in corals over time and geographical scales.

The total bioeroded area in all studied corals (fossil and recent) was very low, reaching a maximum value of $3.74 \%$ (Table $1 \mathrm{~A}$ ). Similar values were observed by Sammarco \& Risk (1990) for Porites corals in offshore continental shelf reefs on the Great Barrier Reef (GBR), However, corals from inshore reefs, documented in their study, showed higher degrees of bioerosion (up to $15 \%$ ). All corals in our research were sampled from inshore reefs (see 'Materials and Methods'); thus, the observed percent of bioerosion reported in this study can be considered relatively low.

Several authors (e.g. Highsmith 1981b, Sammarco \& Risk 1990) have suggested coral skeletal density as an important factor controlling bioerosion activity. Samples of Porites lobata from the Gulf of Eilat have a density of ca $1.6 \mathrm{~g} \mathrm{~cm}^{-3}$ (Klein 1989). Lough \& Barnes (1990) measured skeletal density of the same species, sampled from an inshore reef on the GBR, as ca $1.2 \mathrm{~g}$ $\mathrm{cm}^{-3}$. Risk \& Sammarco (1991) reported a significant increase of skeletal density of $P$. lobata with distance from shore. This may partially explain the relatively low bioerosion intensity in Red Sea corals, which is comparable to the intensity observed in offshore reef corals on the GBR. The relatively low excavation intensity, indicated by our data, is in agreement with these observed for corresponding skeletal densities of Porites (see Fig. 2 in Highsmith 1981b).

Worms proved to be the most abundant borers, both in modern and fossil corals (responsible for 35 to $47 \%$ of the total eroded area measured for corals from the various reefs). It is generally accepted in the literature that sponges constitute the major group of boring organisms (Risk \& Sammarco 1982, Highsmith et al. 1983). Sammarco \& Risk (1990) found this to be true only for offshore reefs (GBR), while in inshore reefs bivalves were the dominant group. Our finding of polychaete worms as the most dominant borers is in accordance with Davies \& Hutchings (1983). These authors found similar importance of worms inhabiting Porites skeletons at Lizard Island, GBR. In the present study, sponges were found to be relatively less abundant, in contrast to other studies (e.g. Hein \& Risk 1975, MacGeachy 1977). Notably, the dominance of worms was similar in fossil and modern corals.

As indicated in Fig. 2B, there was no significant difference in the total bioeroded area among the studied reefs $(p>0.05)$. Additionally, the relative importance of each taxon in the composition of the eroding communities was similar (Fig. 3). The highest similarities were demonstrated by worms and bivalves (ca $42 \%$ and $19 \%$, respectively). All other eroding groups were less consistent, showing variation within a narrow range (10 to $30 \%$ ). These variations resulted in a significant statistical interaction between 'taxon' and 'reef', indicating slight differences in the eroding community structure (2-way ANOVA, p $<0.05)$,

Fossil Porites corals collected from Sinai terraces exhibited well-preserved traces of ancient bioeroders in form of burrows and chambers. Despite the fact that fossil corals are subjected to sequences of progressive diagenesis (Gvirtzman \& Friedman 1977), the eroded boreholes remained detectable. Some of the eroded cavities were preserved in their original form (Fig. 1B), while other burrows experienced various stages of infilling (Fig. 1C). However, the secondary infilling material of subsequent deposition could be readily distinguished by different patterns of colour and texture. Therefore, we were able to successfully document individual traces. No attempt was made to identify the nature of the infilling material (see Jones \& Pemberton 1988)

The number of bioeroding individuals was significantly different among the studied reefs (SF, SR, ER), with a considerably higher number in Sinai fossil (SF) reefs (Fig. 2A). These observations may suggest different environmental conditions influencing the abundance of eroding organisms.

An important question concerning palaeontological processes in fossil corals is whether all the observed burrows and holes were originally excavated during the life time of the coral or as a consequence of postgrowth events. An example of such an event is the removal of living tissue while the coral is still submerged and exposed to bioerosion. The plausibility of such events may be diminished by the following arguments: (1) Sponges are often recognized as the first invading macro-eroders of exposed dead carbonate substrate (Warme 1975, Highsmith 1981a). In this case, we would expect to find a higher infestation by sponges in dead submerged corals. By contrast, we found that the relative area eroded by sponges was the lowest in fossil corals $(10 \%)$. (2) Two modes of bioerosion patterns were observed in the coral slabs: burrows which were restricted to the base and periphery regions and burrows which were distributed randomly. In most of the modern living corals the burrows were restricted to the basal and peripheral regions of the slabs, although several corals showed random distribution (Fig. 1). In fossil corals, the distribution pattern of bioerosion traces shows approximately equal proportions of these 2 modes. In some cases, where the border line between the former living region (represented by calices) and dead region (represented by encrusted skeletal matter) of the fossil coral could be detected, the boreholes were restricted to the latter. The living tissue may act as a barrier against activity of eroding agents (Hubbard 1972, 
Highsmith 1981a). Hence, in fossil samples showing basal and peripheral distribution (Fig. 1), living tissue was undoubtedly present. Since bioeroders are found also in central regions of modern corals (Fig. 1), the random distribution in fossils does not necessarily imply post-growth erosion.

Despite a higher number of traces of eroding individuals found in the fossils, the total eroded area was similar to that found in recent reefs (Fig. 2). At this stage it is still difficult to interpret this observation. A possible explanation might be a different composition within each taxon.

In all variables measured (i.e. number of individuals, total eroded area and relative percent of erosion) the data showed markedly high standard deviations (Table 1A, B, Fig. 2). This high variation is in accordance with previous studies (e.g. Highsmith 1981a, Sammarco \& Risk 1990). A possible explanation for these deviations might be the intrinsic heterogeneity of the corals as a living habitat, due to their location, growth forms and growth rates. Both fossil and modern corals show similar high deviations in the intensity of bioerosion.

Highsmith (1980) suggested that there is a strong relation between the bioerosional damage to coral skeletons and plankton primary productivity. According to this theory, increased productivity provides an energy source for a variety of new food chains including organisms that bore into coral skeletons. Sammarco \& Risk (1990) also suggested that internal bioerosion may be linked to levels of productivity, as shown by the cross-continental-shelf trend they found for bioerosion activity in Porites colonies. We interpret our observations of a higher number of eroders in fossil Porites from the Sinai emerged reefs as a possible indication of changes in the level of primary productivity in the Red Sea during periods of highstand sea level. Palaeoclimatical evidence from the region shows that during the late Quaternary reefforming peaks the climate was wetter than the present desert conditions, resulting in terrestrial runoffs carrying organic compounds (e.g humic substances) into the reet environment (Klein et al. 1990). These compounds, derived largely from degraded plant material (Isdale \& Kotwicki 1987), probably enriched the surrounding marine ecosystem in nutrients. The enriched marine environment of the late Quaternary may have been typified by a higher level of primary productivity than at present. As shown by Smith et al. (1981), past nutrient enrichment has resulted in acceleration of internal bioerosion intensity

Our results stress the necessity for comparative studies of bioeroder communities in modern and ancient reef corals in order to evaluate the impact of eroding agents over reef history.
Acknowledgements. We thank Mrs $\mathrm{O}$. Leshem of Ichilov Hospital, Tel Aviv, for helping with X-radiography work and Mr A. Vinkler for sample preparation and technical assistance. We thank the MBL at Eilat, especially Dr A. Genin, for use of lab facilities. Special thanks are due to the anonymous referees for their constructive comments that greatly improved the manuscript. This research was supported by a grant from the National Council for Research and Development, Israel, and the Ministry of Science and Technology (MOST) (Joint German-Israeli Research Program).

\section{LITERATURE CITED}

Bromley, R. G., Hanken, N.-M., Asgaard, U. (1990). Shallow marine bioerosion: preliminary results of an experimental study. Bull. Geol. Soc. Den. 38: 85-99

Davies, P. J., Hutchings, P. A. (1983). Initial colonization, erosion and accretion on coral substrate. Coral Reefs 2: $27-35$

Gvirtzman, G., Buchbinder, B., Shen, A., Nir, Y., Friedman, G. M. (1977). Morphology of the Red Sea fringing reefs: a result of the erosional pattern of the last-glacial low-stand sea level and the following holocene recolonization. Mem. Bur. Rech. Geol. Min. 89: 480-491

Gvirtzman, G., Friedman, G. M. (1977). Sequence of progressive diagenesis in coral reefs. Stud. Geol. 4: 357-380

Gvirtzman, G., Friedman, G. M., Miller, D. S. (1973). Control and distribution of uranium in coral reefs during diagenesis. J. sedim. Petrol. 43: 985-997

Hein, F. J., Risk, M. J. (1975). Bioerosion of coral heads: Inner patch reefs, Florida reef tract. Bull. mar. Sci. 25: 133-138

Highsmith, R. C. (1980). Geographic patterns of coral bioerosion: A productivity hypothesis. J. exp. mar. Biol. Ecol. 46 . $177-196$

Highsmith, R. C. (1981a). Coral bioerosion at Enewetak agents and dynamics. Int. Rev. ges. Hydrobiol. 66: 335-375

Highsmith, R. C. (1981b) Coral bioerosion: damage relative to skeletal density. Am. Nat. 117: 193-198

Highsmith, R. C., Lueptow, R. L., Schonberg, S. C. (1983) Growth and bioerosion of three massive corals on Belize barrier reef. Mar. Ecol. Prog. Ser. 13: 261-271

Hubbard, J. A. E. B. (1972). Cavity formation in living scleractinian reef corals and fossil analogues. Geol. Rdsch. 61 $551-564$

Hutchings, P. A. (1986). Biological destruction of coral reefs Coral Reefs 4: 239-252

Hutchings, P. A., Peyrot-Clausade, M. (1988). Macro-infaunal boring communities of Porites: a brogeographical comparison. Proc. 6th Int. Coral Reef Symp. 3: 263-267

Isdale. P. J., Kotwicki, V (1987). Lake Eyre and the Great Barrier Reef: a paleohydrological ENSO connection. South Austr. Geogr. J. 87: 44-55

Jones, B., Pemberton, S G. (1988). Lithophaga bonngs and their influence on the diagenesis of corals in the Pleistocene Ironshore formation of Grand Cayman Island, British West Indies. Palaios 3: 3-21

Kiene, W. E. (1988). A model of bioerosion on the Great Barrier Reef. Proc. 6th Int. Coral Reef Symp. 3: 449-454

Klein, R. (1989). Sclerochronological aspects of hermatypic corals (Genus: Porites) in the Gulf of Eilat. M.Sc. dissertation, Tel Aviv University

Klein, R., Loya, Y., Gvirtzman, G., Isedale, P. J., Susic, M. (1990). Seasonal rainfall in the Sinai desert during the late Quarternary inferred from fluorescent bands in fossil corals. Nature, Lond. 345: 145-147 
Lough, J. M., Barnes, D. J. (1990). Intra-annual timing of density band formation of Porites coral from the central Great Barrier Reef. J exp. mar Biol. Ecol. 135: 35-57

Loya, Y. (1972). Community structure and species diversity of hermatypic corals at Eilat, Red Sea. Mar Biol. 13: 100-123

Loya, Y., Slobodkin, L. B. (1971). The coral reefs of Eilat (Gulf of Eilat, Red Sea). Symp. Zool. Soc. Lond. 28: 117-139

MacGeachy, J. K. (1977). Factors controlling sponge boring in Barbados reef corals. Proc. 3rd Int Coral Reef Symp. 2: $478-483$

Peyrot-Clausade, M., Brunel, J. F. (1990). Distribution patterns of macroboring organisms on Tulear flats (SW Madagascar). Mar. Ecol. Prog. Ser. 61 133-144

Risk, M. J., MacGeachy, J. K. (1978). Aspects of bioerosion of modern Caribbean reefs. Revta Biol. trop. 26 (Suppl. 1): 85-105

Risk, M. J., Sammarco, P. W. (1982). Bioerosion of corals and

This article was submitted to the editor the influence of damselfish territoriality: a preliminary study. Oecologia 52: 376--380

Risk, M. J., Sammarco, P. W. (1991) Cross-shelf trends in skeletal density of the massive coral Purites lobata from the Great Barrier Reef. Mar. Ecol. Prog. Ser. 69: 195-200

Sammarco, P. W., Risk, M. J. (1990). Large-scale patterns in internal bioerosion of Porites: cross continental shelf trends on the Great Barrier Reef. Mar. Ecol. Prog. Ser. 59: 145-156

Smith, S. V., Kimmerer, W. J., Laws, E. A., Brock, R. E., Walsh, T W (1981). Kaneohe Bay sewerage diversion experiment: perspectives on ecosystem responses to nutritional perturbation. Pacif. Sci. 35: 279-395

Sokal, R. R., Rohlf, F. J. (1969). Biometry. W. H. Freeman, San Francisco

Warme, J. E. (1975). Boring as trace fossils and the processes of marine bioerosion. In: Frey, R. W. (ed.) The study of trace fossils. Springer-Verlag, New York, p. 181-228

Manuscript first received: February 18, 1991

Revised version accepted: August 14, 1991 